\title{
Response of Chosen American Asparagus officinalis L. Cultivars to Drip Irrigation on the Sandy Soil in Central Europe: Growth, Yield, and Water Productivity
}

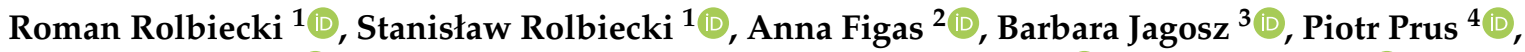 \\ Piotr Stachowski ${ }^{5}$ (D), Maciej J. Kazula ${ }^{6}$, Małgorzata Szczepanek ${ }^{7, *(D)}$, Wiesław Ptach ${ }^{8}$ (D), Ferenc Pal-Fam ${ }^{9}$, \\ Hicran A. Sadan ${ }^{1}$ and Daniel Liberacki ${ }^{5}$ (D)
}

1 Department of Agrometeorology, Plant Irrigation and Horticulture, Faculty of Agriculture and Biotechnology, UTP University of Science and Technology in Bydgoszcz, 85-029 Bydgoszcz, Poland; rolbr@utp.edu.pl (R.R.); rolbs@utp.edu.pl (S.R.); hicran_sadan_76@hotmail.com (H.A.S.)

2 Department of Agricultural Biotechnology, Faculty of Agriculture and Biotechnology, UTP University of Science and Technology in Bydgoszcz, 85-029 Bydgoszcz, Poland; figasanna@utp.edu.pl

3 Department of Plant Biology and Biotechnology, Faculty of Biotechnology and Horticulture, University of Agriculture in Krakow, 31-425 Kraków, Poland; Barbara.Jagosz@urk.edu.pl

4 Laboratory of Economics and Agribusiness Advisory, Department of Agronomy, Faculty of Agriculture and Biotechnology, UTP University of Science and Technology in Bydgoszcz, 85-029 Bydgoszcz, Poland; piotr.prus@utp.edu.pl

check for updates

Citation: Rolbiecki, R.; Rolbiecki, S.; Figas, A.; Jagosz, B.; Prus, P.; Stachowski, P.; Kazula, M.J.; Szczepanek, M.; Ptach, W.; Pal-Fam, F.; et al. Response of Chosen American Asparagus officinalis L. Cultivars to Drip Irrigation on the Sandy Soil in Central Europe: Growth, Yield, and Water Productivity. Agronomy 2021, 11, 864. https://doi.org/10.3390/ agronomy11050864

Academic Editor: Aliasghar Montazar

Received: 31 March 2021

Accepted: 25 April 2021

Published: 28 April 2021

Publisher's Note: MDPI stays neutral with regard to jurisdictional claims in published maps and institutional affiliations.

Copyright: (c) 2021 by the authors. Licensee MDPI, Basel, Switzerland. This article is an open access article distributed under the terms and conditions of the Creative Commons Attribution (CC BY) license (https:// creativecommons.org/licenses/by/ $4.0 /)$
5 Department of Land Improvement, Environmental Development and Spatial Management, Faculty of Environmental Engineering and Mechanical Engineering, Poznań University of Life Sciences, 60-649 Poznań, Poland; piotr.stachowski@up.poznan.pl (P.S.); daniel.liberacki@up.poznan.pl (D.L.)

6 Department of Agronomy and Plant Genetics, University of Minnesota, St. Paul, MN 55108-6024, USA; maciek.kazula@gmail.com

7 Department of Agronomy, Faculty of Agriculture and Biotechnology, UTP University of Science and Technology in Bydgoszcz, 85-029 Bydgoszcz, Poland

8 Department of Remote Sensing and Environmental Research, Institute of Environmental Engineering, Warsaw University of Life Sciences, 02-776 Warszawa, Poland; wieslaw_ptach@sggw.pl

9 Institute of Plant Production, Hungarian University of Agriculture and Life Sciences (MATE), Kaposvár Campus, H-7400 Kaposvár, Hungary; Pal-Fam.Ferenc.Istvan@uni-mate.hu

* Correspondence: Malgorzata.Szczepanek@utp.edu.pl

Abstract: The aim of this study was to verify the response of 13 American asparagus cultivars cultivated for green spear on surface postharvest drip irrigation. Irrigation, used to compensate for periodic deficiencies in precipitation, allows for high- and good-quality crops for many species. The field experiment was carried out in 2006-2008 on a very light sandy soil in central Europe (Poland). Irrigation treatments were applied using the tensiometer indications. Water requirements of asparagus were calculated on the base of reference evapotranspiration and crop coefficients. The following evaluations were made: Height, diameter, and number of summer stalks, as well marketable yield, weight, and number of consumption green spears. Drip irrigation applied for 2 years (2006-2007) in the postharvest period had a positive effect on all studied traits in both summer stalks and green spears in 2007-2008. A significant increase in the height, number, and diameter of summer stalks, as well an increase in the marketable yield, weight, and number of green spears was observed for most of the cultivars. In general, postharvest drip irrigation of asparagus cultivated in very light sandy soil significantly contributes to the increase in productivity of American cultivars of this species.

Keywords: Asparagus officinalis L.; cultivars; spears yield; sandy soil; water requirements; IWUE

\section{Introduction}

Asparagus is a perennial vegetable species. Therefore, choosing the most advantageous cultivars for cultivation is a very important factor in yielding. Thanks to intensive 
breeding work carried out in many countries around the world, new cultivars of asparagus are quickly emerging. New cultivars of asparagus are usually very fertile, with relatively high soil and water requirements [1,2]. Therefore, to obtain maximum marketable yields of a given asparagus cultivar, it is recommended to create optimal growth and development conditions during the growing season. Maximum asparagus production possibilities can be achieved by applying organic and mineral fertilization adapted to species nutritional needs and ensuring optimal humidity, with the use of irrigation supplementing deficiency in precipitation. Due to the specific method of cultivation, i.e., harvesting of spears in early spring, the height and quality of asparagus sprouts depend on the amount of ingredients stored in asparagus rootstocks during the growing season of the previous year [1-3].

In recent years in Poland, asparagus (Asparagus officinalis L.) has been observed as a vegetable gaining increasing economic significance. On the one hand, this phenomenon is related to the increase in exports of asparagus spears to European Union countries (mainly Germany), and on the other hand, with an increase in demand for this valuable vegetable among domestic consumers, changing their eating habits noticeably. Basic "heavy" species of vegetables, primarily root vegetables such as potatoes, carrots, parsley or red beet, are replaced with low-caloric species with high biological and flavor values [1,2].

Asparagus is a plant grown primarily in light soils with low water content, i.e., limited retention capacity [1,4]. On the one hand, due to a deep-reaching and well-developed root system, asparagus is relatively resistant to water deficiency in soil [5-7]. On the other hand, asparagus, as a light soil plant, reacts very positively to irrigation treatments, which are used in the postharvest period, usually from June to August, in the climatic and soil conditions of Central Europe. Postharvest irrigation significantly increases the yield of asparagus spears in the following year [3,4,8-16].

One of the elements of sustainable plant production, which has the task of protecting the soil and plant raw materials, is melioration treatments, among which drip irrigation is of great importance in commercial crops. The aim of the study was to verify the response of 13 chosen American asparagus cultivars grown for green spear production to surface drip irrigation on sandy soil in the region of central Europe (Poland).

\section{Materials and Methods}

\subsection{Plant Material and Location of the Experiment}

The field experiment was carried out in the years 2006-2008 at Kruszyn Krajenski near Bydgoszcz (central Poland) on a sandy soil (Figure 1).

The soil was classified to Typic Hapludolls. The clay content in the topsoil was 7\% and, in the subsoil, the clay content ranged from 3\% to $5 \%$. The average organic matter content was $1.19 \%$. The water reserve to $1 \mathrm{~m}$ depth of soil at field capacity was $87 \mathrm{~mm}$ and the available water was $68 \mathrm{~mm}$. The field experiment was conducted in a randomized block design of a 2-factorial "split-plot" system with 4 replications. The first factor was irrigation used in 2 variants: O-non-irrigated plots (control) and D-drip-irrigated plots. The second factor was 13 American's cultivars asparagus (Asparagus officinalis L.) including Jersey Giant, Jersey Knight, Jersey Supreme, Jersey Deluxe, Jersey King, Atlas, Grande, Apollo, Purple Passion, UC 157, NJ 953, UC 115, and JWC 1. The asparagus crowns were planted 10th of April 2003.

Terms of single irrigation treatments of asparagus were determined on the basis of tensiometer indications according to Horticultural Institut in Geisenheim (Germany) [17]. During the irrigation season, the soil water potential was not less than $-50 \mathrm{kPa}$. The surface drip irrigation of asparagus plants performed done using $16 \mathrm{~mm}$ diameter linear drip line T-Tape, with a $20 \mathrm{~cm}$ distance between the emitters. The flow rate was $51 \mathrm{~m}^{-1} \mathrm{~h}^{-1}$. 


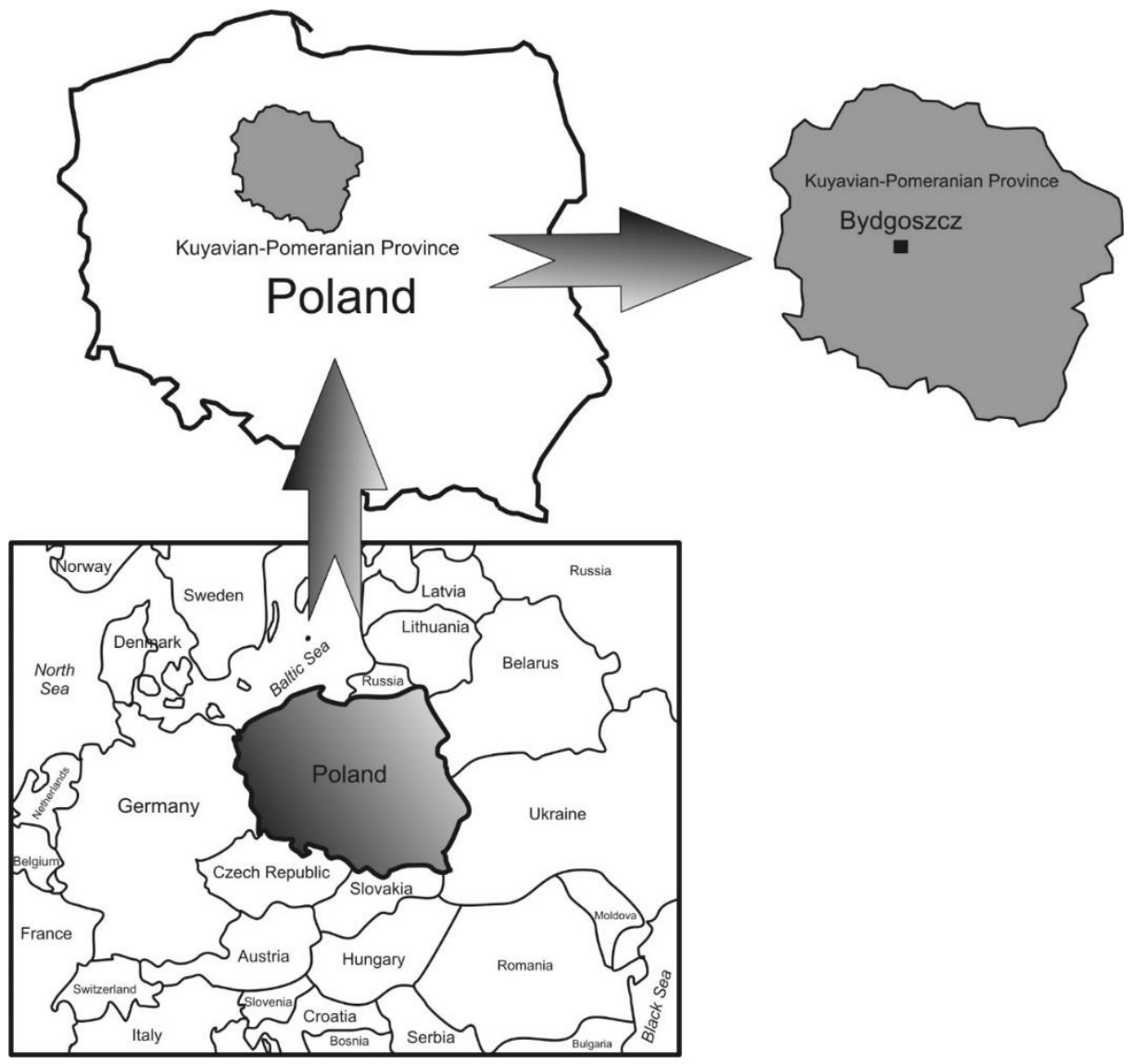

Figure 1. Location of the Bydgoszcz region—within the Kuyavian-Pomeranian Province-in Poland and in Europe.

The standard growing techniques as recommended for asparagus under Polish conditions according to Knaflewski [1] were applied. The asparagus was cultivated for green spears. The plot area for harvest was $15.12 \mathrm{~m}^{2}(24 \mathrm{pcs} \times 35 \mathrm{~cm} \times 180 \mathrm{~cm})$. Green spears were daily collected for 9 (2007) or 10 weeks (2008) depending on the year of harvest. The observation included both summer stalks in the years 2006-2007 and green consuming spears in the years 2007-2008. The following evaluations were made: Height $(\mathrm{cm})$, number, and diameter $(\mathrm{mm})$ of summer stalks, as well as marketable yield $\left(\mathrm{t} \cdot \mathrm{ha} \mathrm{a}^{-1}\right)$, weight $(\mathrm{g})$, and number of green spears. The irrigation water use efficiency (IWUE) was also calculated, which is the quotient of the increase in yield obtained during irrigation and the seasonal dose of water used during irrigation. Irrigation water use efficiency $\left(\mathrm{kg} \cdot \mathrm{ha}{ }^{-1} \cdot \mathrm{mm}^{-1}\right)$, which presents the effectiveness of water use, was calculated for a marketable yield of green spears using the following Equation (1):

$$
\operatorname{IWUE}=\frac{(\mathrm{y}-\mathrm{a})}{\mathrm{x}}
$$

where

$\mathrm{y}=$ yield after irrigation $(\mathrm{kg})$,

$\mathrm{a}=$ yield without irrigation $(\mathrm{kg})$,

$\mathrm{x}=$ seasonal dose of water used in irrigation $(\mathrm{mm})$.

The experimental data height, number, and diameter of summer stalks, as well marketable yield, weight, and number of green spears were statistically processed by variation analysis. Mean values were verified with Tukey's test at a 5\% level. 


\subsection{Assessment of Water and Irrigation Needs}

Reference evapotranspiration (ETo) was determined using Hargreaves' model [18] modified by Droogers and Allen [19] and expressed in Equation (2):

$$
\mathrm{ETo}=\mathrm{HC} \times \mathrm{Ra} \times(\mathrm{Tmax}-\mathrm{Tmin})^{\mathrm{HE}} \times\left(\frac{\mathrm{Tmax}+\mathrm{Tmin}}{2}+\mathrm{HT}\right),(\mathrm{mm})
$$

where

$\mathrm{HC}=$ empirical Hargreaves coefficient $=0.0025$,

$\mathrm{Ra}=$ extraterrestrial radiation $\left(\mathrm{mm} \mathrm{day}^{-1}\right)$,

Tmax $=$ maximum air temperature $\left({ }^{\circ} \mathrm{C}\right)$,

Tmin $=$ minimum air temperature $\left({ }^{\circ} \mathrm{C}\right)$,

$\mathrm{HE}=$ Hargreaves exponent $=0.5$,

$\mathrm{HT}=$ Hargreaves temperature coefficient $=16.8$.

Potencial evapotranspiration (ETp) was determined by the method of crop coefficients [20] using crop coefficients for asparagus as determined by Hargreaveas' model modified by Droogers and Allen [14]. To take into account the specificity of drip irrigation (limited wetted area of soil), Equation (3) was applied [21]:

$$
\mathrm{ETp}=\mathrm{ETo} \times \mathrm{kc} \times \mathrm{kr},(\mathrm{mm})
$$

where

$\mathrm{ETo}=$ reference evapotranspiration $(\mathrm{mm})$,

$\mathrm{kc}=$ crop coefficients,

$\mathrm{kr}=$ reduction coefficients.

Reduction coefficients were determined according to Freeman and Garzoli's formula [22] based on the percentage of surface coverage of asparagus in the postharvest period [14]. The results are presented in Table 1.

Table 1. Values of the correction factor $\mathrm{k}_{\mathrm{r}}$ according to Freeman and Garzoli.

\begin{tabular}{cc}
\hline Area Covering [\%] & Values of Factor $\mathbf{~}_{\mathbf{r}}$ \\
\hline 10 & 0.10 \\
20 & 0.20 \\
30 & 0.30 \\
40 & 0.40 \\
50 & 0.75 \\
60 & 0.80 \\
70 & 0.85 \\
80 & 0.90 \\
90 & 0.95 \\
100 & 1 \\
\hline
\end{tabular}

Drought index (D) according to Stenz [23] is expressed in Equation (4):

$$
\mathrm{D}=\frac{\mathrm{ETo}}{\mathrm{P}}
$$

where

$\mathrm{ETo}=$ reference evapotranspiration $(\mathrm{mm})$,

$\mathrm{P}=$ precipitation in a given period $(\mathrm{mm})$.

To describe the precipitation conditions during the experiment, the worldwide recommended Standardized Precipitation Index (SPI) was used [24]. Equation (5) was used to calculate SPI:

$$
\mathrm{SPI}=\frac{\mathrm{f}(\mathrm{P})-\mu}{\sigma},
$$

where 
$\mathrm{f}(\mathrm{P})=$ transformed totals of precipitation in a given period,

$\mu=$ mean value of the normalized historical precipitation series,

$\sigma=$ mean standard deviation of the normalized historical precipitation series.

\subsection{Meteorological Conditions}

Precipitation conditions in individual decades of the growing and irrigation seasons for asparagus were described according to the season classification, based on the Standardized Precipitation Index, as presented in Table 2.

Table 2. Classification of the period as dependent on Standardized Precipitation Index values [24].

\begin{tabular}{cc}
\hline Period & Standardized Precipitation Index \\
\hline Extreme drought & $\leq-2.00$ \\
Severe drought & from -1.99 to -1.50 \\
Moderate drought & from -1.49 to -1.00 \\
Normal & from -0.99 to 0.99 \\
Moderate wet & from 1.00 to 1.49 \\
Severe wet & from 1.50 to 1.99 \\
Extreme wet & $\geq 2.00$ \\
\hline
\end{tabular}

Numerical data from measurements taken in the meteorological station of the then Department (now the Laboratory) of Land Reclamation and Agrometeorology at the University of Science and Technology located in Mochełek near Bydgoszcz were used in the calculations.

Average air temperature values during the growing season (April-September) in the research years (2006-2007) were higher than in the long-term (1971-2000) by $0.8{ }^{\circ} \mathrm{C}$ and $0.5^{\circ} \mathrm{C}$, respectively (Table 3). In the first year of the study, high air temperature values were found in July $\left(22.4^{\circ} \mathrm{C}\right)$, with the value exceeding the long-term mean by as much as $4.2^{\circ} \mathrm{C}$. In the second year of the study, high air temperature values were found in June $\left(18.2{ }^{\circ} \mathrm{C}\right.$, i.e., $1.9^{\circ} \mathrm{C}$ above the long-term mean).

Table 3. Air temperature $\left({ }^{\circ} \mathrm{C}\right)$ in the 2006-2007 vegetation season.

\begin{tabular}{|c|c|c|c|c|c|c|c|c|}
\hline \multirow{2}{*}{ Year } & \multirow{2}{*}{$\begin{array}{l}\text { 10-Day } \\
\text { Period }\end{array}$} & \multicolumn{6}{|c|}{ Month } & \multirow{2}{*}{ Mean } \\
\hline & & Apr & May & June & July & Aug & Sept & \\
\hline \multirow{4}{*}{2006} & 1 & 5.3 & 12.9 & 11.8 & 22.7 & 17.6 & 15.2 & \\
\hline & 2 & 7.3 & 13.1 & 18.9 & 21.8 & 17.4 & 15.7 & \\
\hline & 3 & 8.7 & 11.4 & 19.7 & 22.7 & 15.0 & 14.6 & \\
\hline & Mean & 7.1 & 12.5 & 16.8 & 22.4 & 16.6 & 15.2 & 15.1 \\
\hline \multirow{4}{*}{2007} & 1 & 5.9 & 9.3 & 18.8 & 15.7 & 18.6 & 12.6 & \\
\hline & 2 & 9.3 & 12.7 & 19.5 & 21.1 & 18.6 & 11.3 & \\
\hline & 3 & 10.2 & 19.0 & 16.2 & 17.3 & 16.4 & 13.2 & \\
\hline & Mean & 8.5 & 13.8 & 18.2 & 18.0 & 17.8 & 12.4 & 14.8 \\
\hline \multicolumn{2}{|c|}{$\begin{array}{l}\text { Mean for } \\
2006-2007\end{array}$} & 7.8 & 13.1 & 17.5 & 20.2 & 17.2 & 13.8 & 14.9 \\
\hline \multicolumn{2}{|c|}{$\begin{array}{l}\text { Mean for } \\
1971-2000\end{array}$} & 7.6 & 13.1 & 16.3 & 18.0 & 17.7 & 13.1 & 14.3 \\
\hline \multicolumn{2}{|c|}{ Difference $(+/-)$} & +0.2 & 0.0 & +1.3 & +2.2 & -0.5 & +0.7 & +0.6 \\
\hline
\end{tabular}

Total precipitation of the growing season in the research years, in relation to the longterm mean, was higher by $54 \mathrm{~mm}$ (i.e., by $19 \%$ ) (Table 4). Higher precipitation totals were recorded in the year 2007 (367 mm, i.e., 131\% of the long-term mean). Particularly heavy rainfall occurred in June and July 2007, amounting to $103 \mathrm{~mm}$ and $112 \mathrm{~mm}$, respectively, which constituted $172 \%$ or $167 \%$ of the long-term mean. In the first year of the study, the highest rainfall was recorded in August (115 mm, i.e., 225\% of the long-term mean). 
Table 4. Rainfalls (mm) in the 2006-2007 vegetation season.

\begin{tabular}{|c|c|c|c|c|c|c|c|c|}
\hline \multirow{2}{*}{ Year } & \multirow{2}{*}{$\begin{array}{l}\text { 10-Day } \\
\text { Period }\end{array}$} & \multicolumn{6}{|c|}{ Month } & \multirow{2}{*}{ Mean } \\
\hline & & Apr & May & June & July & Aug & Sept & \\
\hline \multirow{4}{*}{2006} & 1 & 0 & 10 & 7 & 0 & 75 & 37 & \\
\hline & 2 & 0 & 20 & 15 & 26 & 23 & 0 & \\
\hline & 3 & 45 & 34 & 0 & 5 & 17 & 4 & \\
\hline & Mean & 45 & 64 & 22 & 31 & 115 & 42 & 317 \\
\hline \multirow{4}{*}{2007} & 1 & 5 & 21 & 43 & 79 & 3 & 18 & \\
\hline & 2 & 0 & 23 & 24 & 4 & 11 & 5 & \\
\hline & 3 & 3 & 5 & 36 & 29 & 46 & 13 & \\
\hline & Mean & 8 & 49 & 103 & 112 & 60 & 36 & 367 \\
\hline \multicolumn{2}{|c|}{$\begin{array}{l}\text { Mean for } \\
2006-2007\end{array}$} & 26 & 56 & 62 & 71 & 87 & 39 & 342 \\
\hline \multicolumn{2}{|c|}{$\begin{array}{c}\text { Mean for } \\
1971-2000\end{array}$} & 25 & 43 & 60 & 67 & 51 & 42 & 288 \\
\hline \multicolumn{2}{|c|}{ Difference $(+/-)$} & +1 & +13 & +2 & +4 & +36 & -3 & +54 \\
\hline
\end{tabular}

Air temperature during the harvest of asparagus spears (from the third decade of April to the third decade of June) is a very important element of asparagus cultivation $[1,14]$.

\subsection{Irrigation Needs}

Irrigation was carried out after the harvest period, during the summer months, as recommended [25]. In 2006, irrigation began on July 4 and ended on August 31. The irrigation season lasted 59 days. During the time, 10 single doses were used, amounting to $92 \mathrm{~mm}$. In 2007, the irrigation season was shorter and lasted 37 days (from 15 July to 20 August). A total of $54 \mathrm{~mm}$ water was used in 6 doses.

The values of Stenz index, presented in Table 5, indicate the irrigation needs of asparagus cultivars in July and August of the years 2006 and 2007.

Table 5. Values of the Stenz index for the 2006-2007 irrigation period.

\begin{tabular}{ccc}
\hline \multirow{2}{*}{ Year } & \multicolumn{3}{c}{ Month } \\
\cline { 2 - 3 } & July & August \\
\hline 2006 & 6.2 & 0.9 \\
2007 & 1.2 & 2.1 \\
\hline
\end{tabular}

The values of the Standardized Precipitation Index, summarized in Table 6, reflect the actual precipitation conditions occurring in individual decades of the irrigation season. The first decade of July in 2006 was extremely dry, while the second decade of July in 2007 was moderately dry.

Table 6. Values of the Stenz index for the 2006-2007 irrigation period.

\begin{tabular}{cccc}
\hline \multirow{2}{*}{ Month } & 10-Days Period & \multicolumn{2}{c}{ Year } \\
\cline { 3 - 4 } & 1 & $\mathbf{2 0 0 6}$ & $\mathbf{2 0 0 7}$ \\
\hline \multirow{2}{*}{ July } & 2 & -2.17 & 2.00 \\
& 3 & 0.08 & -1.49 \\
\multirow{3}{*}{ August } & 1 & -0.63 & 0.68 \\
& 2 & 1.95 & -0.69 \\
& 3 & 0.69 & 0.06 \\
& & 0.31 & 1.17 \\
\hline
\end{tabular}


The smallest daily water needs under drip irrigation (below $1 \mathrm{~mm}$ ) were found in the third decade of June when summer stalks were just beginning to grow (Figure 2). However, irrigation needs were much higher in the next 2 months of the irrigation season (from $3.2 \mathrm{~mm}$ to $4.4 \mathrm{~mm}$ ). Depending on weather conditions (particularly temperature), asparagus irrigation needs variation in individual years. For comparison, in 9 years of trials with European cultivars (Gijnlim, Ramos, Vulkan) conducted in central Poland (region of Bydgoszcz), the average daily value of field water consumption at drip irrigated plots in June, July, and August, was $1.7 \mathrm{~mm}, 3.5 \mathrm{~mm}$, and $4.4 \mathrm{~mm}$, respectively [14]. In the lysimeter studies by Paschold, et al. [12] daily water consumption under drip irrigation was, on average, $1.6 \mathrm{~mm}$ in June, $2 \mathrm{~mm}$ in July, and $3 \mathrm{~mm}$ in August.

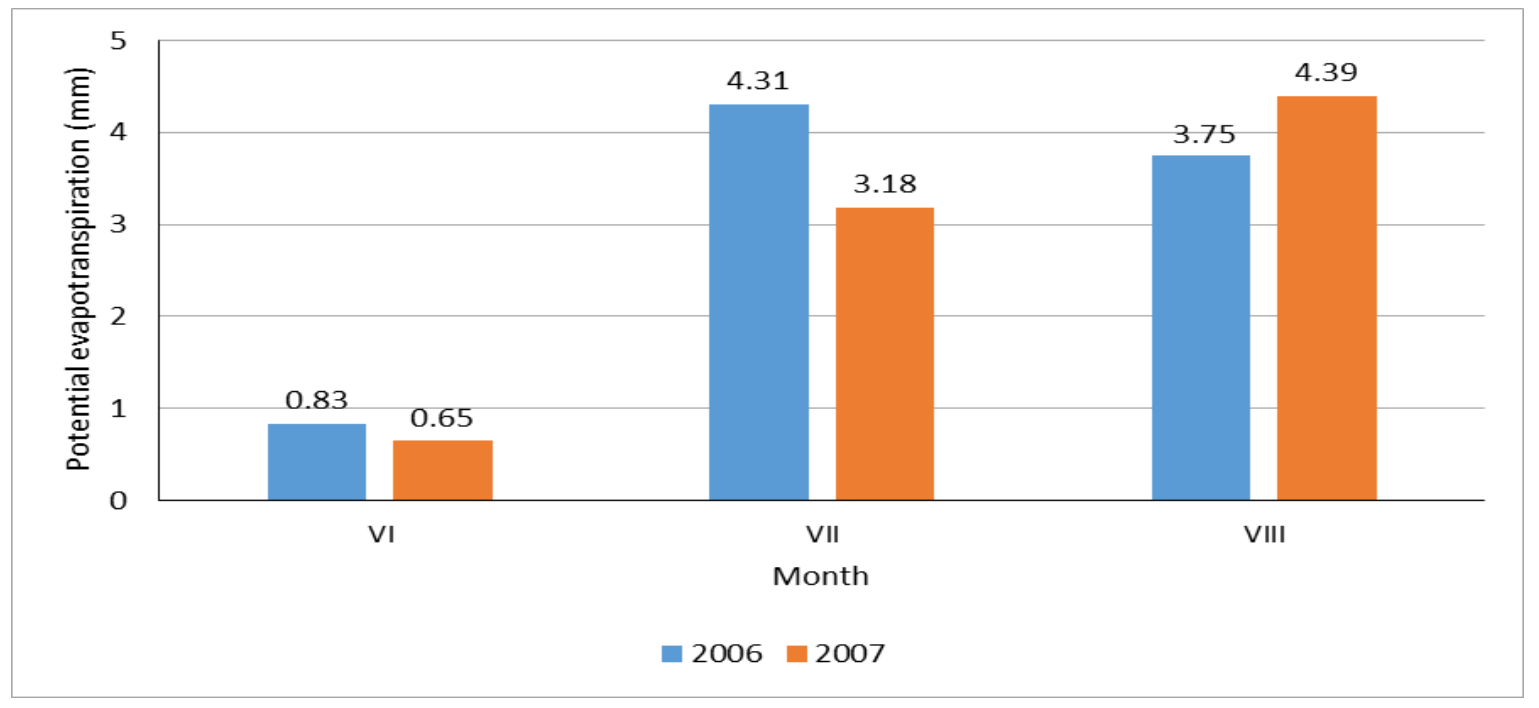

Figure 2. Daily values of the potential evapotranspiration $(\mathrm{mm})$ of the asparagus plants under drip irrigation conditions in particular months of the irrigation period.

The total water needs of asparagus in the postharvest period were higher in the first year of the study $(258 \mathrm{~mm})$ than in the second year of the study $(241 \mathrm{~mm})$ (Figure 3). For comparison, in the Rolbiecki study [14], the water needs of asparagus plants under drip irrigation ranged from $205 \mathrm{~mm}$ to $272 \mathrm{~mm}$ in individual years. The results of tests carried out by Paschold and Kunzelmann [26] in Germany's climatic conditions indicated that the water needs of asparagus plants from June 20 to September 1 ranged between 150-241 mm. Moreover, in prior studies carried out in Germany, Hartmann [8] estimated that, depending on precipitation conditions, the water needs of asparagus plants ranged between $179 \mathrm{~mm}$ and $240 \mathrm{~mm}$. In turn, Pardo et al. [27] recorded the seasonal water consumption of asparagus under lysimeter conditions ranging from $274 \mathrm{~mm}$ to $294 \mathrm{~mm}$. In the latest research on asparagus water needs in various regions of Poland reported by Rolbiecki et al. [28], the irrigation needs of asparagus plants were found to be, on average, $228 \mathrm{~mm}$ in the period from July 1 to August 31 in the central-north-west region of Poland, which also covers the area considered in the present study. 


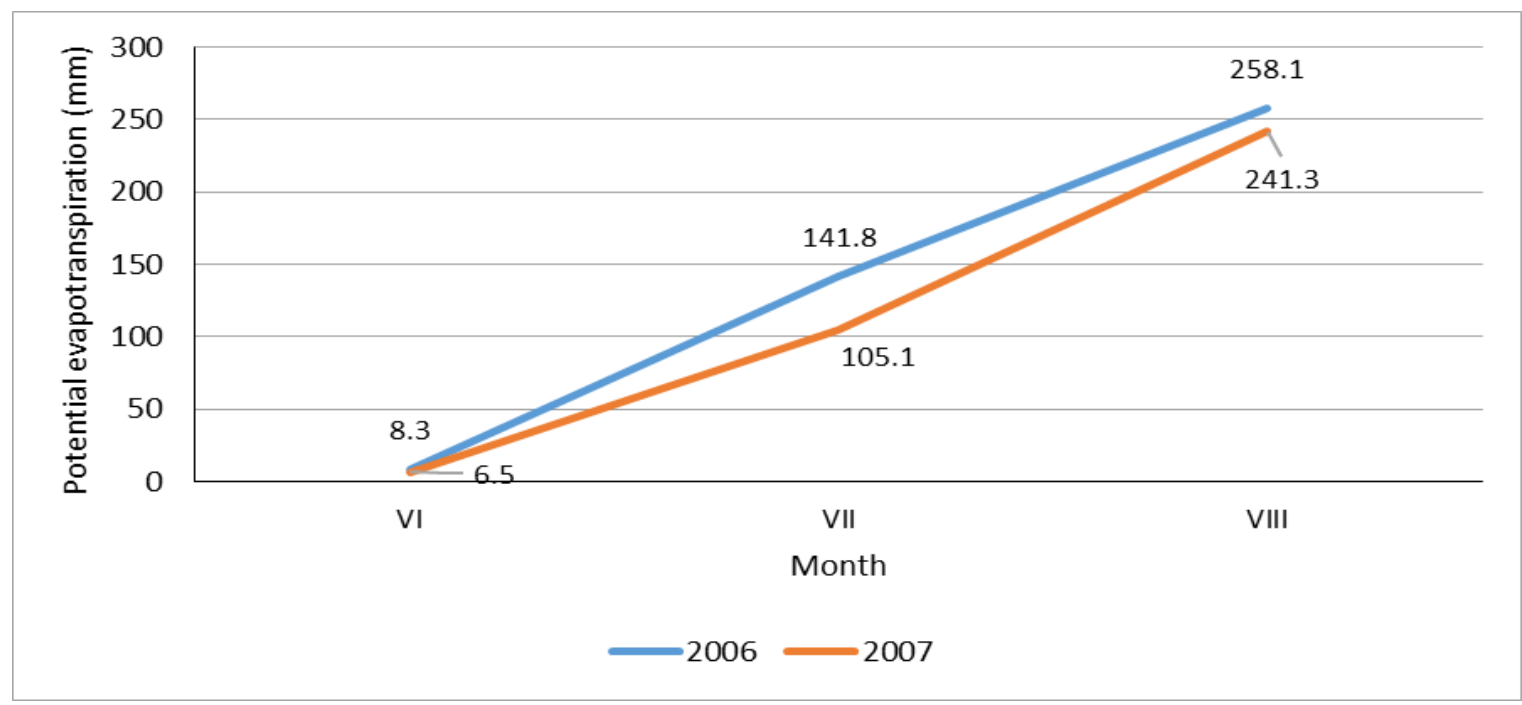

Figure 3. Cumulative potential evapotranspiration $(\mathrm{mm})$ of the asparagus plants under drip irrigation conditions in particular months of the irrigation period.

\section{Results and Discussion}

\subsection{Height, Number, and Diameter of Asparagus Summer Stalks}

Drip irrigation, used after the green spears harvest in the growing season preceding the next asparagus harvest, significantly increased the height of asparagus summer stalks for the studied cultivars and years, on average, from $152 \mathrm{~cm}$ to $172 \mathrm{~cm}$ (Table 7). Stalk height due to drip irrigation increased, on average, by $20 \mathrm{~cm}(13 \%)$. The highest increase in stalk height (above $180 \mathrm{~cm}$ ) under drip irrigation, on average, for 2 years of research, was obtained for the cultivars Apollo $(196 \mathrm{~cm})$, Grande $(185 \mathrm{~cm})$, Atlas $(182 \mathrm{~cm})$, Jersey King, and Purple Passion $(181 \mathrm{~cm})$. The best response to drip irrigation, with reference to this characteristic, was noted in Atlas cultivar. Drip irrigation increased the height of its summer stalks by $40 \mathrm{~cm}$ (i.e., by $28 \%$ ). Some researchers have also shown a significant impact of irrigation on the height of summer stalks in the year preceding the harvest. For example, in the third and fourth year of cultivation, Drost and Wilcox-Lee [29], Hartmann [8,9], Pardo et al. [27], Paschold et al. [12], and Sterrett et al. [30] obtained an average increase in summer stalk height of $14 \mathrm{~cm}$ in comparison to non-irrigated control variants.

Table 7. Height of the asparagus summer stalks $(\mathrm{cm})$ as dependent on cultivar and irrigation.

\begin{tabular}{|c|c|c|c|c|c|c|c|c|c|}
\hline \multirow{2}{*}{ Cultivar } & \multicolumn{3}{|c|}{ Control (Without Irrigation) } & \multicolumn{3}{|c|}{ Drip Irrigation } & \multicolumn{3}{|c|}{ Increase of the Height of Summer Stalks } \\
\hline & 2006 & 2007 & Mean & 2006 & 2007 & Mean & 2006 & 2007 & Mean \\
\hline Jersey Giant & 133 & 139 & 136 & 164 & 168 & 166 & 31 & 29 & 30 \\
\hline Jersey Knight & 158 & 161 & 159 & 166 & 175 & 170 & 8 & 14 & 11 \\
\hline Jersey Supreme & 149 & 151 & 150 & 165 & 169 & 167 & 16 & 18 & 17 \\
\hline Jersey Deluxe & 151 & 155 & 153 & 161 & 180 & 170 & 10 & 25 & 17 \\
\hline Jersey King & 156 & 162 & 159 & 179 & 183 & 181 & 23 & 21 & 22 \\
\hline Atlas & 139 & 145 & 142 & 179 & 185 & 182 & 40 & 40 & 40 \\
\hline Grande & 160 & 165 & 162 & 181 & 190 & 185 & 21 & 25 & 23 \\
\hline Apollo & 169 & 172 & 170 & 192 & 201 & 196 & 23 & 29 & 26 \\
\hline Purple Passion & 150 & 155 & 152 & 178 & 185 & 181 & 28 & 30 & 29 \\
\hline UC 157 & 141 & 146 & 143 & 166 & 176 & 171 & 25 & 30 & 27 \\
\hline NJ 953 & 155 & 161 & 158 & 158 & 170 & 164 & 3 & 9 & 6 \\
\hline UC 115 & 159 & 162 & 160 & 159 & 171 & 165 & 0 & 9 & 4 \\
\hline JWC 1 & 122 & 149 & 135 & 130 & 157 & 143 & 8 & 8 & 8 \\
\hline Mean & 149 & 156 & 152 & 165 & 178 & 172 & 18 & 22 & 20 \\
\hline
\end{tabular}

2006: $\mathrm{LSD}_{0.05}$ for: Irrigation = 6.343; Cultivars = 16.591; Interaction: Cultivars $/$ Irrigation $=25.831$; Irrigation/Cultivars $=13.599 .2007$ : $\mathrm{LSD}_{0.05}$ for: Irrigation $=7.225$; Cultivars $=14.739$; Interaction: Cultivars $/$ Irrigation $=22.341$; Irrigation $/$ Cultivars $=12.664 .2006-2007$ : $\mathrm{LSD}_{0.05}$ for: Irrigation $=2.663$; Cultivars $=11.936$; Interaction: Cultivars $/$ Irrigation $=16.879$; Irrigation $/$ Cultivars $=9.603$. 
Postharvest drip irrigation, applied in the growing season preceding the next asparagus harvest, significantly increased the number of asparagus summer stalks per plant for the studied cultivars and years, on average, from 7.9 to 11.1 (Table 8). Stalk number per plant due to drip irrigation increased, on average, by 3.2 pcs (40\%). The highest increase in stalk number per plant (12 and more) under drip irrigation, on average, for 2 years of research, was observed for Jersey King (13.3), Apollo (12.6), Jersey Supreme, Atlas, and UC 157 (12) cultivars. The best response to drip irrigation, with reference to this characteristic, was noted in UC 157 and Grande. Drip irrigation increased the number of stalks per plant of these cultivars by 5.0 and 5.1 pcs (i.e., by $72 \%$ ), respectively. The positive impact of drip irrigation on the increase in the number of summer stalks was also presented for Germany's weather conditions, which are similar to Polish weather conditions, by Hartmann [9], Hartmann et al. [10], and Paschold et al. [12]. Drost [31] reported that under dry climatic conditions, lowering sandy soil moisture below $-50 \mathrm{kPa}$ reduced the number and height of stalks in comparison to drip-irrigated variants. Sterrett et al. [30] obtained an increase in stalk number due to irrigation, on average, of four stalks per plant, and Battilani [32] obtained an increase of one stalk per plant. The diverse response of asparagus cultivars to drip irrigation has been confirmed, i.a., by the results of Dutch [33] and Polish [14] studies.

Table 8. Number of the asparagus summer stalks (pcs) as dependent on cultivar and irrigation.

\begin{tabular}{|c|c|c|c|c|c|c|c|c|c|}
\hline \multirow{2}{*}{ Cultivar } & \multicolumn{3}{|c|}{ Control (Without Irrigation) } & \multicolumn{3}{|c|}{ Drip Irrigation } & \multicolumn{3}{|c|}{ Increase of the Number of Summer Stalks } \\
\hline & 2006 & 2007 & Mean & 2006 & 2007 & Mean & 2006 & 2007 & Mean \\
\hline Jersey Giant & 8.1 & 7.6 & 7.8 & 10.6 & 10.2 & 10.4 & 2.5 & 2.6 & 2.5 \\
\hline Jersey Knight & 6.7 & 7.0 & 6.8 & 10.5 & 10.7 & 10.6 & 3.8 & 3.7 & 3.7 \\
\hline Jersey Supreme & 8.0 & 8.2 & 8.1 & 12.1 & 11.9 & 12.0 & 4.1 & 3.7 & 3.9 \\
\hline Jersey Deluxe & 8.5 & 7.9 & 8.2 & 9.7 & 10.0 & 9.8 & 1.2 & 2.1 & 1.6 \\
\hline Jersey King & 10.5 & 10.3 & 10.4 & 13.2 & 13.5 & 13.3 & 2.7 & 3.2 & 2.9 \\
\hline Atlas & 9.2 & 8.8 & 9.0 & 12.1 & 12.0 & 12.0 & 2.9 & 3.2 & 3.0 \\
\hline Grande & 6.8 & 7.1 & 6.9 & 12.0 & 11.9 & 11.9 & 5.2 & 4.8 & 5.0 \\
\hline Apollo & 8.7 & 9.1 & 8.9 & 12.3 & 12.9 & 12.6 & 3.6 & 3.8 & 3.7 \\
\hline Purple Passion & 8.3 & 7.9 & 8.1 & 8.8 & 9.1 & 8.9 & 0.5 & 1.2 & 0.8 \\
\hline UC 157 & 7.1 & 6.8 & 6.9 & 11.8 & 12.2 & 12.0 & 4.7 & 5.4 & 5.0 \\
\hline NJ 953 & 8.5 & 8.1 & 8.3 & 10.7 & 11.2 & 10.9 & 2.2 & 3.1 & 2.6 \\
\hline UC 115 & 6.8 & 7.3 & 7.0 & 10.6 & 11.5 & 11.0 & 3.8 & 4.2 & 4.0 \\
\hline JWC 1 & 7.2 & 6.9 & 7.0 & 9.1 & 9.0 & 9.0 & 1.9 & 2.1 & 2.0 \\
\hline Mean & 8.0 & 7.9 & 7.9 & 11.0 & 11.2 & 11.1 & 3.0 & 3.3 & 3.2 \\
\hline
\end{tabular}

2006: $\mathrm{LSD}_{0.05}$ for: Irrigation $=0.870 ;$ Cultivars $=2.190$; Interaction: Cultivars $/$ Irrigation $=3.655 ;$ Irrigation $/$ Cultivars $=2.413 .2007: \mathrm{LSD}_{0.05}$ for: Irrigation $=0.987$; Cultivars $=1.839$; Interaction: Cultivars/Irrigation $=3.196$; Irrigation/Cultivars $=2.417 .2006-2007:$ LSD 0.05 for: Irrigation $=1.160 ;$ Cultivars $=0.719 ;$ Interaction: Cultivars $/$ Irrigation $=1.017 ;$ Irrigation $/$ Cultivars $=0.578$.

Drip irrigation, used after the harvest in the growing season preceding the next asparagus harvest, significantly increased the diameter of asparagus summer stalks for the studied cultivars and years, on average, from $11.2 \mathrm{~mm}$ to $12.6 \mathrm{~mm}$ (Table 9). Stalk diameter due to drip irrigation increased, on average, by $1.3 \mathrm{~mm}(12 \%)$. The highest increase in stalk diameter under drip irrigation, on average, for 2 years of research, was observed for Apollo $(15.3 \mathrm{~mm})$ and Grande $(14.6 \mathrm{~mm})$ cultivars. The best response to drip irrigation, with reference to this characteristic, was also noted in Apollo and Grande. Drip irrigation increased the diameter of their summer stalks by $3.6 \mathrm{~mm}$ and $3.2 \mathrm{~mm}$, respectively (i.e., by $31 \%$ and 29\%). Researchers such as, i.a., Sterrett et al. [30], Contador [34], Rubio [35], and Battilani [32], also observed a significant impact of drip irrigation on stalk diameter. As numerous authors have stated, irrigation significantly affects the growth of summer stalks and, consequently, the yield of asparagus spears in the next year [4,36-41]. Based on the results of a cultivar trial in 2003 (carried out as part of the third IACT) in which 31 asparagus cultivars were compared, Rolbiecki and Rolbiecki [2] found a significant impact of drip irrigation on the formation of summer stalks and marketable yield in the first harvest season. The impact of irrigation was manifested by the increased accumulation of carbohydrates in 
asparagus rootstocks of the plants growing in optimal humidity conditions, used in spring of the next harvest year $[30,31,42-48]$.

Table 9. Diameter of the asparagus summer stalks ( $\mathrm{mm})$ as dependent on cultivar and irrigation.

\begin{tabular}{|c|c|c|c|c|c|c|c|c|c|}
\hline \multirow{2}{*}{ Cultivar } & \multicolumn{3}{|c|}{ Control (Without Irrigation) } & \multicolumn{3}{|c|}{ Drip Irrigation } & \multicolumn{3}{|c|}{ Increase of the Diameter of Summer Stalks } \\
\hline & 2006 & 2007 & Mean & 2006 & 2007 & Mean & 2006 & 2007 & Mean \\
\hline Jersey Giant & 10.6 & 10.3 & 10.4 & 10.8 & 11.2 & 11.0 & 0.2 & 0.9 & 0.5 \\
\hline Jersey Knight & 12.6 & 12.3 & 12.4 & 12.0 & 13.5 & 12.7 & -0.6 & 1.2 & 0.3 \\
\hline Jersey Supreme & 10.0 & 9.1 & 9.5 & 11.9 & 12.2 & 12.0 & 1.9 & 3.1 & 2.5 \\
\hline Jersey Deluxe & 11.6 & 11.2 & 11.4 & 11.4 & 12.3 & 11.8 & -0.2 & 1.1 & 0.4 \\
\hline Jersey King & 13.2 & 12.4 & 12.8 & 13.0 & 13.6 & 13.3 & -0.2 & 1.2 & 0.5 \\
\hline Atlas & 14.0 & 11.2 & 12.6 & 11.0 & 13.8 & 12.4 & -3.0 & 2.6 & -0.2 \\
\hline Grande & 11.4 & 11.4 & 11.4 & 14.5 & 14.8 & 14.6 & 3.1 & 3.4 & 3.2 \\
\hline Apollo & 11.8 & 11.5 & 11.6 & 15.0 & 15.6 & 15.3 & 3.2 & 4.1 & 3.6 \\
\hline Purple Passion & 12.3 & 11.7 & 12.0 & 10.4 & 13.5 & 11.9 & -1.9 & 1.8 & 0.0 \\
\hline UC 157 & 11.8 & 11.6 & 11.7 & 10.4 & 12.9 & 11.6 & -1.4 & 1.3 & 0.0 \\
\hline NJ 953 & 10.5 & 10.1 & 10.3 & 13.2 & 13.7 & 13.4 & 2.7 & 3.6 & 3.1 \\
\hline UC 115 & 9.5 & 9.8 & 9.6 & 11.3 & 11.9 & 11.6 & 1.8 & 2.1 & 1.9 \\
\hline JWC 1 & 10.0 & 10.2 & 10.1 & 10.8 & 12.6 & 11.7 & 0.8 & 2.4 & 1.6 \\
\hline Mean & 11.5 & 11.0 & 11.2 & 12.0 & 13.2 & 12.6 & 0.5 & 2.2 & 1.3 \\
\hline
\end{tabular}

2006: $\mathrm{LSD}_{0.05}$ for: Irrigation = ns; Cultivars = 3.293; Interaction: Cultivars/Irrigation = 4.657; Irrigation/Cultivars $=2.677 .2007$ : LSD 0.05 for: Irrigation $=0.143$; Cultivars $=1.532$; Interaction: Cultivars $/$ Irrigation $=3.221$; Irrigation $/$ Cultivars $=2.774 .2006-2007$ : LSD 0.05 for: Irrigation = 0.499; Cultivars = 2.234; Interaction: Cultivars /Irrigation = 3.159; Irrigation $/$ Cultivars $=1.797$.

\subsection{Marketable Yield, Weight and Number of Asparagus Green Spears}

Postharvest drip irrigation treatment of asparagus plants used in the growing season preceding the asparagus harvest significantly increased green spear yields from $4.21 \mathrm{t} \cdot \mathrm{ha}^{-1}$ to $6.23 \mathrm{t} \cdot \mathrm{ha}^{-1}$ in the next growing season (Table 10). The marketable yield increase in green spears due to drip irrigation for the studied cultivars and 2 years of research was, on average, $2.02 \mathrm{t} \cdot \mathrm{ha}^{-1}(48 \%)$. The highest marketable yield increase under drip irrigation-above $7 \mathrm{t} \cdot \mathrm{ha}^{-1}$, on average, for 2 years of research-was obtained for Apollo, NJ 953, Jersey Deluxe, and Grande cultivars. High marketable yields above $6 \mathrm{t} \cdot \mathrm{ha}^{-1}$ were obtained for UC 157, Jersey King, UC 115, Jersey Supreme, and Jersey Giant cultivars. Marketable yields above $5 \mathrm{t} \cdot \mathrm{ha}^{-1}$ were obtained for Purple Passion and Jersey Knight. The lowest yields under drip irrigation (above $4 \mathrm{t} \cdot \mathrm{ha}^{-1}$ ) were collected from JWC 1 and Atlas. The best response to drip irrigation was noted in Jersey Deluxe and Jersey Giant. Drip irrigation increased their marketable yields by $4.37 \mathrm{t} \cdot \mathrm{ha}^{-1}(157 \%)$ and $3.91 \mathrm{t} \cdot \mathrm{ha}^{-1}(142 \%)$, respectively. No significant response to drip irrigation was found in Purple Passion, Jersey King, and Atlas. The response to drip irrigation in other tested cultivars was positive, and the observed marketable yield increases ranged from $1.71 \mathrm{t} \cdot \mathrm{ha}^{-1}$ to $2.78 \mathrm{t} \cdot \mathrm{ha} \mathrm{a}^{-1}(35-79 \%)$. The results obtained are consistent with the results of studies conducted by other scientists. Hartmann $[8,9]$, in weather conditions characteristic for Germany, obtained yield increases of $50 \%$ in his trials on sandy soil and $25 \%$ on loamy sand due to drip irrigation. Moreover, Paschold et al. $[4,11,13]$, carrying out a cultivar trial using drip irrigation, recorded the highest marketable yields for Gijnlim cultivar. In Poland, Rolbiecki [14] also obtained the highest marketable yields for both control (no irrigation) $\left(6.5 \mathrm{t} \cdot \mathrm{ha}^{-1}\right)$ and drip irrigated plots $\left(10.9 \mathrm{t} \cdot \mathrm{ha}^{-1}\right)$ for Gijnlim. Pinkau and Grutz [49] obtained significantly lower marketable yield increases in spears, on average, of $12.4 \%$, observing the highest yield increases in dry years. Mulder and Lavrijsen [33], in an asparagus cultivar trial under sprinkler irrigation conducted in the Netherlands, obtained the highest yields for Gijnlim, amounting to $4.5 \mathrm{t} \cdot \mathrm{ha} \mathrm{a}^{-1}$ in the first harvest year and $12.8 \mathrm{t} \cdot \mathrm{ha}^{-1}$ in the second year. Numerous other authors have also presented a significant impact of irrigation on yield increases in asparagus spears grown in different than Polish climate zones $[15,16,29,30,47]$. 
Table 10. Marketable yield of the asparagus green spears $\left(\mathrm{t} \cdot \mathrm{ha}^{-1}\right)$ as dependent on cultivar and irrigation.

\begin{tabular}{|c|c|c|c|c|c|c|c|c|c|}
\hline \multirow{2}{*}{ Cultivar } & \multicolumn{3}{|c|}{ Control (Without Irrigation) } & \multicolumn{3}{|c|}{ Drip Irrigation } & \multicolumn{3}{|c|}{ Increase of the Marketable Yield of Green Spears } \\
\hline & 2007 & 2008 & Mean & 2007 & 2008 & Mean & 2007 & 2008 & Mean \\
\hline Jersey Giant & 2.55 & 2.95 & 2.75 & 6.46 & 6.87 & 6.66 & 3.91 & 3.92 & 3.91 \\
\hline Jersey Knight & 3.43 & 3.51 & 3.47 & 5.64 & 5.81 & 5.72 & 2.21 & 2.30 & 2.25 \\
\hline Jersey Supreme & 4.18 & 4.32 & 4.25 & 6.16 & 6.70 & 6.43 & 1.98 & 2.38 & 2.18 \\
\hline Jersey Deluxe & 2.66 & 2.91 & 2.78 & 6.96 & 7.34 & 7.15 & 4.30 & 4.43 & 4.37 \\
\hline Jersey King & 6.15 & 5.80 & 5.97 & 6.04 & 6.50 & 6.27 & -0.11 & 0.70 & 0.30 \\
\hline Atlas & 4.57 & 4.41 & 4.49 & 4.67 & 4.92 & 4.79 & 0.10 & 0.51 & 0.30 \\
\hline Grande & 5.42 & 4.80 & 5.11 & 6.91 & 7.25 & 7.08 & 1.49 & 2.45 & 1.97 \\
\hline Apollo & 5.77 & 5.40 & 5.58 & 7.21 & 7.84 & 7.52 & 1.44 & 2.44 & 1.94 \\
\hline Purple Passion & 5.75 & 5.01 & 5.38 & 4.96 & 5.64 & 5.30 & -0.79 & 0.63 & -0.08 \\
\hline UC 157 & 4.16 & 3.98 & 4.07 & 5.72 & 6.58 & 6.15 & 1.56 & 2.60 & 2.08 \\
\hline NJ 953 & 5.13 & 4.22 & 4.67 & 6.93 & 7.51 & 7.22 & 1.80 & 3.29 & 2.55 \\
\hline UC 115 & 3.11 & 3.96 & 3.53 & 5.75 & 6.87 & 6.31 & 2.64 & 2.91 & 2.78 \\
\hline JWC 1 & 2.51 & 2.89 & 2.70 & 3.91 & 4.91 & 4.41 & 1.40 & 2.02 & 1.71 \\
\hline Mean & 4.26 & 4.17 & 4.21 & 5.95 & 6.52 & 6.23 & 1.69 & 2.35 & 2.02 \\
\hline
\end{tabular}

2007: $\mathrm{LSD}_{0.05}$ for: Irrigation $=0.473 ;$ Cultivars $=1.572$; Interaction: Cultivars $/$ Irrigation $=2.223$; Irrigation $/$ Cultivars $=1.274 .2008: \mathrm{LSD}_{0.05}$ for: Irrigation $=0.581$; Cultivars $=1.822$; Interaction: Cultivars $/$ Irrigation $=2.451$; Irrigation $/$ Cultivars $=1.422 .2007-2008: L_{0} D_{0.05}$ for: Irrigation $=0.211 ;$ Cultivars $=0.946 ;$ Interaction: Cultivars $/$ Irrigation $=1.337 ;$ Irrigation $/$ Cultivars $=0.761$

Drip irrigation, used after the harvest in the next growing season preceding the asparagus harvest, significantly increased the mean spear weight from $35.33 \mathrm{~g}$ to $40.35 \mathrm{~g}$ (Table 11). The mean spear weight due to drip irrigation increased for the studied cultivars and 2 years of research, on average, by $5.02 \mathrm{~g}(14 \%)$. The greatest mean spear weight under drip irrigation-above $40 \mathrm{~g}$, on average, for 2 years of research - was obtained for the cultivars Grande (48.79 g), Jersey Knight (43.32 g), Apollo (43.03 g), Purple Passion $(42.99 \mathrm{~g})$, Atlas $(42.71 \mathrm{~g})$, and UC 115 (41.24 g). The best response to drip irrigation, with reference to this characteristic, was noted in Atlas and UC 115 cultivars. Drip irrigation increased the mean spear weight by $24 \%$ and $32 \%$, respectively. For comparison, the spear weight for Gijnlim cultivar in asparagus trials under irrigation conducted by Mulder and Lavrijsen [33] was approximately $40 \mathrm{~g}$. Paschold et al. [13] obtained values at the level of $35 \mathrm{~g}$, and Sterret et al. [30] obtained values at the level of $25 \mathrm{~g}$.

Table 11. Weight of the asparagus green spears $(\mathrm{g})$ as dependent on cultivar and irrigation.

\begin{tabular}{|c|c|c|c|c|c|c|c|c|c|}
\hline \multirow{2}{*}{ Cultivar } & \multicolumn{3}{|c|}{ Control (Without Irrigation) } & \multicolumn{3}{|c|}{ Drip Irrigation } & \multicolumn{3}{|c|}{ Increase of the Weight of Green Spears } \\
\hline & 2007 & 2008 & Mean & 2007 & 2008 & Mean & 2007 & 2008 & Mean \\
\hline Jersey Giant & 25.02 & 26.02 & 25.52 & 34.51 & 36.31 & 35.41 & 9.49 & 10.29 & 9.89 \\
\hline Jersey Knight & 36.77 & 38.22 & 37.49 & 42.33 & 44.31 & 43.32 & 5.56 & 6.09 & 5.83 \\
\hline Jersey Supreme & 37.63 & 36.61 & 37.12 & 35.95 & 39.45 & 37.70 & -1.68 & 2.84 & 0.58 \\
\hline Jersey Deluxe & 32.87 & 31.81 & 32.34 & 35.39 & 38.40 & 36.89 & 2.52 & 6.59 & 4.55 \\
\hline Jersey King & 42.86 & 34.76 & 38.81 & 35.19 & 40.19 & 37.69 & -7.67 & 5.43 & -1.12 \\
\hline Atlas & 34.80 & 34.22 & 34.51 & 41.70 & 43.73 & 42.71 & 6.90 & 9.51 & 8.20 \\
\hline Grande & 43.55 & 42.55 & 43.05 & 48.29 & 49.30 & 48.79 & 4.74 & 6.75 & 5.74 \\
\hline Apollo & 36.95 & 38.55 & 37.75 & 42.05 & 44.01 & 43.03 & 5.10 & 5.46 & 5.28 \\
\hline Purple Passion & 39.46 & 39.46 & 39.46 & 40.99 & 44.99 & 42.99 & 1.53 & 5.53 & 3.53 \\
\hline UC 157 & 35.97 & 32.97 & 34.47 & 37.49 & 39.50 & 38.49 & 1.52 & 6.53 & 4.02 \\
\hline NJ 953 & 37.52 & 36.52 & 37.02 & 36.78 & 39.88 & 38.33 & -0.74 & 3.36 & 1.31 \\
\hline UC 115 & 30.23 & 32.33 & 31.28 & 40.24 & 42.24 & 41.24 & 10.01 & 9.91 & 9.96 \\
\hline JWC 1 & 29.95 & 31.05 & 30.50 & 37.44 & 38.44 & 37.94 & 7.44 & 7.39 & 7.44 \\
\hline Mean & 35.66 & 35.01 & 35.33 & 39.10 & 41.60 & 40.35 & 3.44 & 6.59 & 5.02 \\
\hline
\end{tabular}

2007: $\mathrm{LSD}_{0.05}$ for: Irrigation = ns; Cultivars $=8.822$; Interaction: Cultivars /Irrigation $=11.316$; Irrigation $/$ Cultivars $=7.066 .2008: \mathrm{LSD}_{0.05}$ for: Irrigation $=6.343$; Cultivars $=6.022$; Interaction: Cultivars $/$ Irrigation $=9.416$; Irrigation $/$ Cultivars $=6.116 .2007-2008:$ LSD 0.05 for: Irrigation $=1.031 ;$ Cultivars $=4.622 ;$ Interaction: Cultivars $/$ Irrigation $=6.536 ;$ Irrigation $/$ Cultivars $=3.718$.

Drip irrigation, applied after the harvest in the growing season preceding the next asparagus harvest, significantly increased the number of green spears per plant from 6.50 
to 9.49 (Table 12). Green spears number per plant increased due to drip irrigation for the studied cultivars and 2 years of research, on average, by 2.98 pcs $(46 \%)$. The highest increase in green spears number per plant (10 or more) under drip irrigation conditions, on average, for 2 years of research, was observed for the cultivars Jersey Deluxe (11.10), Jersey King (10.90), Jersey Supreme (10.78), Jersey Giant (10.72), NJ 953 (10.46), and Apollo (10.00). The best response to drip irrigation, with reference to this characteristic, was noted in Jersey Deluxe cultivar. Drip irrigation increased the number of green spears per plant in this cultivar by more than six spears (i.e., by 123\%). Hartmann [9], Paschold et al. [11], Rolbiecki and Rolbiecki [2], and Rolbiecki [14] also obtained an increase in the number of asparagus spears due to drip irrigation.

Table 12. Number of the asparagus green spears (pcs) as dependent on cultivar and irrigation.

\begin{tabular}{|c|c|c|c|c|c|c|c|c|c|}
\hline \multirow{2}{*}{ Cultivar } & \multicolumn{3}{|c|}{ Control (Without Irrigation) } & \multicolumn{3}{|c|}{ Drip Irrigation } & \multicolumn{3}{|c|}{ Increase of the Number of Green Spears } \\
\hline & 2007 & 2008 & Mean & 2007 & 2008 & Mean & 2007 & 2008 & Mean \\
\hline Jersey Giant & 5.20 & 6.30 & 6.25 & 10.17 & 11.27 & 10.72 & 4.97 & 4.97 & 4.97 \\
\hline Jersey Knight & 5.44 & 5.50 & 5.47 & 7.64 & 8.02 & 7.83 & 2.20 & 2.52 & 2.36 \\
\hline Jersey Supreme & 6.60 & 7.60 & 7.10 & 10.27 & 11.30 & 10.78 & 3.67 & 3.7 & 3.68 \\
\hline Jersey Deluxe & 4.94 & 5.02 & 4.98 & 11.65 & 10.55 & 11.10 & 6.71 & 5.53 & 6.12 \\
\hline Jersey King & 8.41 & 8.44 & 8.42 & 10.35 & 11.45 & 10.90 & 1.94 & 3.01 & 2.47 \\
\hline Atlas & 6.49 & 6.22 & 6.35 & 7.53 & 8.53 & 8.03 & 1.04 & 2.31 & 1.67 \\
\hline Grande & 6.47 & 6.01 & 6.24 & 8.20 & 8.65 & 8.42 & 1.73 & 2.64 & 2.18 \\
\hline Apollo & 7.10 & 6.92 & 7.01 & 9.69 & 10.32 & 10.00 & 2.59 & 3.40 & 2.99 \\
\hline Purple Passion & 8.66 & 9.66 & 9.16 & 7.32 & 10.32 & 8.82 & -1.34 & 0.66 & -0.34 \\
\hline UC 157 & 6.77 & 5.61 & 6.19 & 9.07 & 9.84 & 9.45 & 2.30 & 4.23 & 3.26 \\
\hline NJ 953 & 7.81 & 7.01 & 7.41 & 10.87 & 10.05 & 10.46 & 3.06 & 3.04 & 3.05 \\
\hline UC 115 & 4.46 & 5.21 & 4.83 & 8.56 & 9.22 & 8.89 & 4.10 & 4.01 & 4.05 \\
\hline JWC 1 & 5.17 & 6.20 & 5.68 & 7.15 & 8.83 & 7.99 & 1.98 & 2.63 & 2.30 \\
\hline Mean & 6.42 & 6.59 & 6.50 & 9.11 & 9.87 & 9.49 & 2.69 & 3.28 & 2.98 \\
\hline
\end{tabular}

2007: $\mathrm{LSD}_{0.05}$ for: Irrigation $=0.747 ;$ Cultivars $=2.116$; Interaction: Cultivars $/$ Irrigation $=2.993 ;$ Irrigation $/$ Cultivars $=1.732 .2008: \mathrm{LSD}_{0.05}$ for: Irrigation $=0.824$; Cultivars $=1.811$; Interaction: Cultivars $/$ Irrigation $=2.459$; Irrigation/Cultivars $=1.562 .2007-2008: L_{0.05}$ for: Irrigation $=0.372 ;$ Cultivars $=1.666$; Interaction: Cultivars $/$ Irrigation $=2.356$; Irrigation $/$ Cultivars $=1.340$.

\subsection{Irrigation Water Use Efficiency}

The average value of irrigation water use efficiency (IWUE) for the harvest years and cultivars was $31 \mathrm{~kg} \cdot \mathrm{ha}^{-1} \cdot \mathrm{mm}^{-1}$ (Table 13). Irrigation water use efficiency in the first year of research (2007) was lower $\left(19 \mathrm{~kg} \cdot \mathrm{ha}^{-1} \cdot \mathrm{mm}^{-1}\right)$ than in the second year of study (2008) $\left(44 \mathrm{~kg} \cdot \mathrm{ha}^{-1} \cdot \mathrm{mm}^{-1}\right)$. This was due to the fact that, for the irrigation season in 2006, a higher seasonal irrigation norm was used than in 2007. Obviously, asparagus yields harvested at drip irrigated plots in 2007 were the result of irrigation carried out in 2006, and, respectively, postharvest irrigation carried out in 2007 had an impact on asparagus yields harvested in 2008. Jersey Deluxe and Jersey Giant were characterized by the highest IWUE, which, on average, for 2 years of research, was $64 \mathrm{~kg} \cdot \mathrm{ha}^{-1} \cdot \mathrm{mm}^{-1}$ and $57 \mathrm{~kg} \cdot \mathrm{ha}^{-1} \cdot \mathrm{mm}^{-1}$, respectively. The lowest IWUE $\left(4 \mathrm{~kg} \cdot \mathrm{ha}^{-1} \cdot \mathrm{mm}^{-1}-6 \mathrm{~kg} \cdot \mathrm{ha}^{-1} \cdot \mathrm{mm}^{-1}\right)$ was found in Atlas, Jersey King, and Purple Passion cultivars. The other tested cultivars, on average, for 2 years of research, were described by IWUE as ranging from $26 \mathrm{~kg} \cdot \mathrm{ha}^{-1} \cdot \mathrm{mm}^{-1}$ to $41 \mathrm{~kg} \cdot \mathrm{ha}^{-1} \cdot \mathrm{mm}^{-1}$. Diverse irrigation water use efficiency in the cultivation of various asparagus cultivars has been confirmed by the results of previous trials conducted in the central Poland (region of Bydgoszcz) with other cultivars of asparagus [2,14] and vegetable species $[50,51]$ or berry plants [52-55]. 
Table 13. Irrigation water use efficiency $\left(\mathrm{kg} \cdot \mathrm{ha}^{-1} \cdot \mathrm{mm}^{-1}\right)$ as dependent on cultivar and year studied.

\begin{tabular}{cccc}
\hline \multirow{2}{*}{ Cultivar } & \multicolumn{3}{c}{ Irrigation Water Use Efficiency } \\
\cline { 2 - 4 } & $\mathbf{2 0 0 7}$ & $\mathbf{2 0 0 8}$ & Mean \\
\hline Jersey Giant & 42 & 73 & 57 \\
Jersey Knight & 24 & 43 & 33 \\
Jersey Supreme & 22 & 44 & 33 \\
Jersey Deluxe & 47 & 82 & 64 \\
Jersey King & - & 13 & 6 \\
Atlas & - & 9 & 4 \\
Grande & 16 & 45 & 30 \\
Apollo & 16 & 45 & 30 \\
Purple Passion & - & 12 & 6 \\
UC 157 & 17 & 48 & 32 \\
NJ 953 & 20 & 61 & 40 \\
UC 115 & 29 & 54 & 41 \\
JWC 1 & 15 & 37 & 26 \\
Mean & 19 & 44 & 31 \\
\hline
\end{tabular}

\section{Conclusions}

Drip irrigation of 13 cultivars of asparagus, applied for 2 years in the postharvest period (2006-2007), had a positive effect on all studied characteristics in both summer stalks and consumption green spears of this vegetable. On average, in 2006-2007, a significant increase in the height, number, and diameter of summer stalks was visible in 13,12, and 9 of 13 studied asparagus cultivars, respectively. On average, in 2007-2008, the increase in marketable yield, weight, and number of green spears was significant for 12, 11, and 12 of 13 tested asparagus cultivars, respectively. The highest marketable yield increase of green spears under drip irrigation-above $7 \mathrm{t} \cdot \mathrm{ha}^{-1}$, on average, for 2 years of research-was obtained for Jersey Deluxe, Grande, Apollo, and NJ 953 cultivars. The best response to drip irrigation was noted in Jersey Deluxe and Jersey Giant. Drip irrigation increased the marketable yields of these cultivars by $157 \%$ and $142 \%$, respectively. Jersey Deluxe and Jersey Giant cultivars were characterized by the highest irrigation water use efficiency (calculated for the marketable yield of green spears), which, on average, for 2 years of research, was $64 \mathrm{~kg} \cdot \mathrm{ha}^{-1} \cdot \mathrm{mm}^{-1}$ and $57 \mathrm{~kg} \cdot \mathrm{ha}^{-1} \cdot \mathrm{mm}^{-1}$, respectively. High irrigation water use efficiency, over $30 \mathrm{~kg} \cdot \mathrm{ha}^{-1} \cdot \mathrm{mm}^{-1}$, was observed in the case of 9 of 13 tested cultivars. In summary, postharvest irrigation of asparagus cultivated on a very light sandy soil significantly improved both the summer stalk characteristics, as well as the marketable yield features of consumption green spears of this vegetable species. Drip irrigation of asparagus, applied after the harvest in the growing season preceding the next green spears harvest, makes it possible to significantly increase the productivity of this vegetable, which contributes to the sustainable crop production.

Author Contributions: Conceptualization-R.R., S.R., and A.F.; methodology-R.R., S.R., and A.F.; software-R.R., S.R., and A.F.; validation-R.R., P.S., and F.P.-F.; formal analysis-R.R., P.S., D.L., and F.P.-F.; investigation-R.R., S.R., and A.F.; resources-R.R. and S.R.; data curation-R.R. and S.R.; writing—original draft preparation-R.R., S.R., A.F., B.J., P.S., W.P., P.P., M.J.K., and H.A.S.; writing—review and editing—R.R., S.R., A.F., B.J., P.S., W.P., P.P., M.S., and M.J.K.; visualization—R.R., S.R., B.J., P.P., F.P.-F., M.J.K., and H.A.S.; supervision-R.R., S.R., B.J., P.P., F.P.-F., M.S., and M.J.K. All authors have read and agreed to the published version of the manuscript.

Funding: This research received no external funding.

Institutional Review Board Statement: Not applicable.

Informed Consent Statement: Not applicable.

Conflicts of Interest: The authors declare no conflict of interest. 


\section{References}

1. Knaflewski, M. Szparag [Asparagus]; Ha-Ka: Komorniki, Poland, 1995; pp. 3-92.

2. Rolbiecki, R.; Rolbiecki, S. Effect of surface drip irrigation on asparagus cultivars in central Poland. Acta Hortic. 2008, 776, 45-50. [CrossRef]

3. Wichrowska, D.; Rolbiecki, R.; Rolbiecki, S.; Jagosz, B.; Ptach, W.; Kazula, M.; Figas, A. Concentrations of some chemical components in white asparagus spears depending on the cultivar and post-harvest irrigation treatments. Folia Hort. 2018, 30, 147-154. [CrossRef]

4. Paschold, P.J.; Hermann, G.; Artelt, B. Asparagus varieties tested over 6 years. Gemüse 1999, 35, $261-266$.

5. Kaniszewski, S. Nawadnianie Warzyw Polowych [Irrigation of Field Vegetables]; PlantPress: Kraków, Poland, 2005 ; pp. 3-115.

6. Kaniszewski, S. Technologia nawadniania warzyw. In Proceedings of the Nawadnianie warzyw w uprawach polowych, Skierniewice, Poland, 12-13 July 2005; pp. 5-19.

7. Kaniszewski, S. Nawadnianie Warzyw [Irrigation of Vegetables]. In Nawadnianie Roślin [Plant Irrigation]; Nowak, L., Karczmarczyk, S., Eds.; PWRiL: Poznań, Poland, 2006; pp. 295-332.

8. Hartmann, H.D. Die Bewasserung bei Spargel und ihre Auswikung auf die Pflanze. Arch. Gart. 1981, 29, 167-175.

9. Hartmann, H.D. The influence of irrigation on the development and yield of asparagus. Acta Hortic. 1981, 119, 309-316. [CrossRef]

10. Hartmann, H.D.; Hermann, G.; Kirchner-Ness, R. Effect of weather during the vegetative period on the yield of asparagus in the following year. Gartenbauwissenschaft 1990, 55, 30-34.

11. Paschold, P.J.; Hermann, G.; Artelt, B. Comparison of international asparagus cultivars under Rhine-Valley conditions in Germany. Acta Hortic. 1996, 415, 257-262. [CrossRef]

12. Paschold, P.J.; Artelt, B.; Hermann, G. The water need of asparagus (Asparagus officinalis L.) determined in a lysimeter station. Acta Hortic. 2004, 664, 529-536. [CrossRef]

13. Paschold, P.J.; Artelt, B.; Hermann, G. Comparison of white asparagus cultivars (Asparagus officinalis L.) in Germany. Acta Hortic. 2008, 776, 379-385. [CrossRef]

14. Rolbiecki, R. Ocena Potrzeb i Efektów Mikronawodnień Szparaga (Asparagus officinalis L.) na Obszarze Szczególnie Deficytowym w Wodę [Assessment of the Needs and Effects of Micro-Irrigation of Asparagus (Asparagus officinalis L.) in an Area Particularly Water-Deficient]; UTP: Bydgoszcz, Poland, 2013; pp. 1-103.

15. Brainard, D.C.; Był, B.; Hayden, Z.D.; Noyes, D.C.; Bakker, J.; Werling, B. Managing drought risk in changing climate: Irrigation and cultivar impact on Michigan asparagus. Agr. Water Manag. 2019, 213, 773-781. [CrossRef]

16. Campi, P.; Mastrorilli, M.; Stellacci, A.M.; Modugno, F.; Palumbo, A.D. Increasing the effective use of water in green asparagus through deficit irrigation strategies. Agr. Water Manag. 2019, 217, 119-130. [CrossRef]

17. Paschold, P.J.; Weithaler, A. Eignung von Sensoren zum Steuern der Bewässerung bei Freilandgemüse. Z. Bewässerungswirtschaft 2000, 35, 51-62.

18. Hargreaves, G.H.; Samani, Z.A. Reference crop evapotranspiration from temperature. Appl. Eng. Agric. 1985, 1, 96-99. [CrossRef]

19. Treder, W.; Wójcik, K.; Żarski, J. Wstępna ocena możliwości szacowania potrzeb wodnych roślin na podstawie prostych pomiarów meteorologicznych [Initial assessment of the possibility of estimating the water needs of plants on the basis of simple meteorological measurements]. Zesz. Nauk. Inst. Sad. Kw. Skiern. 2010, 18, 143-153.

20. Allen, R.G.; Pereira, L.S.; Raes, D.; Smith, M. Crop Evapotranspiration-Guidelines for Computing Crop Water Requirements; FAO Irrigation and Drainage Paper 56; FAO: Rome, Italy, 1998; p. 300.

21. Vermeiren, L.; Jobling, G.A. Localized Irrigation; FAO Irrigation and Drainage Paper 36; FAO: Rome, Italy, $1984 ;$ p. 198.

22. Smith, M. CROPWAT a Computer Program for Irrigation Planning and Management; FAO Irrigation and Drainage Paper 46; FAO; Rome, Italy, 1992; p. 132.

23. Łabędzki, L. Susze rolnicze. Zarys problematyki oraz metody monitorowania i klasyfikacji [Agricultural droughts]. Woda. Środowisko. Obsz. Wiejskie. Rozpr. Nauk. Monogr. 2006, 17, 1-107.

24. McKee, T.B.; Doesken, J.N.; Kleist, J. The Relationship of Drought Frequency and Duration to Time Scales. In Proceedings of the 8th Conference on Applied Climatology, Anaheim, CA, USA, 17-22 January 1993; American Meteorological Society: Boston, MA, USA, 1993; Volume 17, pp. 179-183.

25. Paschold, P.J.; Kleber, J.; Mayer, N. Geisenheimer Bewässerungssteuerung 2002. Z. Bewässerungswirtschaft 2002, $37,5-15$.

26. Paschold, P.J.; Kunzelmann, G. Umweltschonender und Effizienter Bewässerungseinsatz im Gemüseanbau. Praktische Empfehlungen zur Bewässerungss-Teuerung und Bewässerungstechnik im Hessischen Ried; Hessisches Ministerium für Umwelt, Landwirtschaft und Forsten: Wiesbaden, Germany, 2002; pp. 1-23.

27. Pardo, A.; Arbizou, J.; Suso, M.L. Evapotranspiration and crop coefficients in white asparagus. Acta Hortic. 1997, 449, 187-192. [CrossRef]

28. Rolbiecki, S.; Rolbiecki, R.; Jagosz, B.; Ptach, W.; Stachowski, P.; Kazula, M. Water needs of asparagus plants in the different regions of Poland. Annu. Set Environ. Prot. 2019, 21, 1227-1237.

29. Drost, D.T.; Wilcox-Lee, D. Soil water deficits and asparagus: Bud size and subsequent spear growth. Sci. Hortic. 1997, 70, 145-153. [CrossRef]

30. Sterrett, S.B.; Ross, B.B.; Savage, C.P., Jr. Establishment and yield of asparagus as influenced by planting and irrigation method. J. Am. Soc. Hortic. Sci. 1990, 115, 29-33. [CrossRef]

31. Drost, D.T. Soil water deficits reduce growth and yield of asparagus. Acta Hortic. 1999, 479, 383-390. [CrossRef] 
32. Battilani, A. Response of asparagus (Asparagus officinalis L.) to post-harvesting irrigation. Acta Hortic. 1997, 449, 181-187. [CrossRef]

33. Mulder, J.H.; Lavrijsen, P. First results of the "Third International Asparagus Cultivar Trial" planted in Horst, the Netherlands. Acta Hortic. 2008, 776, 367-372. [CrossRef]

34. Contador, F.F. Asparagus (Asparagus officinalis L.) Response to Different Irrigation Regimes and Nitrogen Fertilization Levels. Second Year after Planting. Master's Thesis, University of Chile, Santiago, Chile, 1991; p. 92.

35. Rubio, F.A.H. Irrigation and Nitrogenous Fertilization during the First Establishment Year of an Asparagus Plantation. Master's Thesis, University of Chile, Santiago, Chile, 1992; p. 105.

36. Kaufmann, F. Intensivierung der Spargelproduktion durch Bewasserrung. Gartenbau 1977, 24, 73-74.

37. Bussell, W.T. Asparagus-Irrigation and establishment methods. Asparagus Res. Newsl. 1985, 3, 1-21.

38. Hartmann, H.D. Possibility of predicting asparagus yields in central Europe. In Proceedings of the 6th International Asparagus Symposium, Guelph, ON, Canada, 5-9 August 1985; pp. 318-323.

39. Jerez, B.J.A. Differencial Irrigation in Two-Year Old Asparagus (Asparagus officinalis L.). Master's Thesis, Univ. de Concepcion, Chillan, Chile, 1990; p. 115.

40. Kaufmann, F. Principles of plant density for green asparagus harvested by different methods. Acta Hortic. 1990, 271, 227-233. [CrossRef]

41. Ferreyra, E.R.; Peralta, A.J.M.; van Selles, S.G.; Fritsch, F.N.; Contador, F.F. Asparagus crop (Asparagus officinalis L.) response to different water regimes during the first two establishment seasons. Agric. Tec. 1995, 55, 1-8.

42. Dowtown, W.J.S.; Torokvalvy, W. Photosynnthesis in developing asparagus plants. Aust. J. Plant Physiol. 1975, 2, 367-375.

43. Wilcox-Lee, D. Soil matrics potential, plant water relations and growth in asparagus. Hort. Sci. 1987, $22,22-24$.

44. Pressman, E.; Schaffer, A.A.; Compton, D.; Zamski, E. The effect of low temperature and drought on carbohydrate content of asparagus. J. Plant Physiol. 1989, 134, 209-213. [CrossRef]

45. Pressman, E.; Schaffer, A.A.; Compton, D.; Zamski, E. Carbohydrate content of young asparagus plants as affected by temperature regimes. J. Plant Physiol. 1994, 143, 621-624. [CrossRef]

46. Martin, S.; Hartmann, H.D. The content and distribution of carbohydrates in asparagus. Acta Hortic. 1990, 271, 443-446. [CrossRef]

47. Roth, R.L.; Gardner, B.R. Asparagus yield response to water and nitrogen. Trans. Am. Soc. Agric. Eng. 1989, 32, 105-112. [CrossRef]

48. Drost, D.T. Irrigation budget and plant growth of asparagus. Acta Hortic. 1996, 415, 343-350. [CrossRef]

49. Pinkau, H.; Grutz, E.M. Effect of nitrogen, sprinkler irrigation and length of harvesting period on the yield and quality of green asparagus. Arch. Gart. 1985, 33, 177-189.

50. Rolbiecki, R.; Rolbiecki, S. Effects of micro-irrigation systems on lettuce and radish production. Acta Hortic. 2007, 729, 331-335. [CrossRef]

51. Rolbiecki, R.; Rolbiecki, S.; Figas, A.; Jagosz, B.; Stachowski, P.; Sadan, H.A.; Prus, P.; Pal-Fam, F. Requirements and effects of surface drip irrigation of mid-early potato cultivar Courage on a very light soil in Central Poland. Agronomy 2021, 11, 1-13. [CrossRef]

52. Rolbiecki, S.; Rzekanowski, C. Influence of sprinkler and drip irrigation on the growth and yield of strawberries grown on sandy soils. Acta Hortic. 1997, 439, 669-672. [CrossRef]

53. Rolbiecki, S.; Rolbiecki, R.; Rzekanowski, C. Response of black currant (Ribes nigrum L.) cv. 'Titania' to micro-irrigation under loose sandy soil conditions. Acta Hortic. 2002, 585, 649-652. [CrossRef]

54. Rolbiecki, S.; Rolbiecki, R.; Rzekanowski, C. Effect of micro-irrigation on the growth and yield of raspberry (Rubus idaeus L.) cv. 'Polana' grown in very light soil. Acta Hortic. 2002, 585, 653-657. [CrossRef]

55. Rolbiecki, S.; Rolbiecki, R.; Rzekanowski, C.; Derkacz, M. Effect of different irrigation regimes on growth and yield of 'Elsanta' strawberries planted on loose sandy soil. Acta Hortic. 2004, 646, 163-166. [CrossRef] 